\title{
Preface
}

\section{Theme Issue on Confining Units}

\author{
Vicki Remenda
}

The impetus for this theme issue on confining units came from a Geological Society of America theme session on field investigations into clayey aquitards, co-chaired by Garth van der Kamp and myself (Vicki Remenda) in the autumn of 1998. The response to the session, both in the number of abstracts received and in attendance, indicated that a wide range of research activity is focused on the hydrogeology of clayey confining units, and that a volume dedicated to this topic would be of interest to many readers.

The terms "confining unit" and "aquitard" (used interchangeably in this issue) are historically defined not by what they are, but rather by what they are not, namely aquifers. Clayey aquitards are abundant, contain sufficient clay and/or silt to have low permeability, and although they may be fractured or contain zones of higher permeability material, they transmit water poorly or of insufficient quantity and thus are not usually exploitable for water supply. However, because they generally surround aquifers and have comparatively high specific storage, confining units often control the hydraulics of aquifers. In addition, they usually contain high concentrations of solutes and solids available for hydrogeochemical reactions. Thus, clayey confining units, or aquitards, are deposits of sufficient areal extent and thickness whose hydrogeological and hydrogeochemical characteristics are defined by the presence of clay minerals and clay-sized particles.

This issue comprises eight articles, four of which are topical overviews (van der Kamp 2001; McMahon 2001; Rodvang and Simpkins 2001; Sacchi et al. 2001), and four of which are site reports (Boisson et al. 2001;

Received: 15 November 2000 / Accepted: 20 November 2000 Published online: 13 January 2001

(C) Springer-Verlag 2001

V. Remenda ( $)$

Department of Geological Sciences and Geological Engineering, Queen's University, Kingston, Ontario K7L 3N6, Canada

Present address:

Terrain Sciences Division, Geological Survey of Canada, 615 Booth St., Ottawa, Ontario K1A 0E8, Canada

e-mail: remenda@geol.queensu.ca

Fax: +1-613-5336592
Desbarats et al. 2001; Gautschi 2001; Gerber et al. 2001).

Many aquifer-instrumentation techniques, field and laboratory procedures, and some basic assumptions (Neuzil 1986) cannot necessarily be used to determine either the physical parameters of aquitards (e.g., van der Kamp 2001) or the geochemical and isotopic nature of pore fluids in aquitards (e.g., Sacchi et al. 2001). Neuzil, in his landmark 1986 paper on groundwater in low-permeability environments, states that "the ability to test conceptual models of flow in low-permeability environments is severely limited by constraints of time; response on a large scale takes too long to observe." He suggests that "one way around the problem is to seek evidence for long-term behaviour of porous media by studying the geologic evidence of processes which have been operative for a long time." This approach is particularly relevant to the development of suitable procedures for investigating candidate sites for nuclear-waste repositories. Two such studies appear in this issue. Gautschi (2001) and Boisson et al. (2001) provide overviews of the investigations conducted, respectively, by the Swiss National Cooperative for the Disposal of Radioactive Waste (NAGRA) on the Opalinus clay and by the French Institute for Nuclear Protection and Safety (IPSN) on the Upper Toarcian claystones at the Tournemire site. The results of these studies indicate that confining units of exceptional stability and low permeability are potentially suitable repositories for nuclear and other hazardous waste.

Aquitards can be considered part of the Earth's "plumbing," because ultimately they control both the quantity and quality of water reaching aquifers. For example, Desbarats et al. (2001) report on a geostatistical procedure for estimating large-scale leakance of water through a confining unit that, although it is regionally extensive and generally thick by as much as $50 \mathrm{~m}$, in places also contains "windows," or areas of zero thickness. This unit overlies the Oak Ridges Moraine complex which supplies as much as $25 \%$ of the drinking water to north-suburban Toronto, Canada. Working in the same geographical area and with an adjacent aquitard, Gerber et al. (2001) focus on the syn- and postdepositional features that enable rates of recharge through a dense clayey till to be much higher than would be expected on the basis of smaller-scale permeability. 
As is noted in van der Kamp (2001), heavily pumped confined aquifers could not sustain their current usage without these secondary recharge avenues within the low-permeability matrix.

Confining units generally contain a nearly inexhaustible supply of hydrogeochemical reactants, both in the pore fluid and the adjacent solids. As McMahon (2001) reports, it is in the mixing zones or interfaces between aquifers and aquitards where much of the biogeochemical activity occurs. Rodvang and Simpkins (2001), in their overview of the fate and occurrence of agricultural contaminants in North American aquitards, indicate that the reserves of organic carbon and pyrite in unweathered aquitards have the potential to reduce nitrate and sorb pesticides well into the future. Weathered aquitards, with higher rates of groundwater flow and thus lower concentrations of organic carbon and pyrite, are not as effective in reducing concentrations of agricultural contaminants.

The papers contained in this volume are by no means representative of all of the research currently being conducted in both shallow and deep confining units. The papers do, however, represent an excellent cross section of critical questions: How do we extract representative pore fluid from compacted, clay-rich deposits? What useful transformations occur in aquitards and at aquifer/aquitard interfaces? How do we evaluate the in-situ hydraulic conductivity of confining units on a useful scale? Can we account for both syn- and post-depositional variations in aquitard composition? How do we verify the future stability and safety of nuclear- and other hazardouswaste repositories? I anticipate that these papers will provide the reader with new insights into processes and procedures.
Keywords confining units - general hydrogeology · equipment/field techniques $\cdot$ hydraulic properties . laboratory experiments/measurements

\section{References}

Boisson J-Y, Bertrand L, Heitz J-F, Moreau-Le Golvany Y (2001) In situ and laboratory investigations of fluid flow through an argillaceous formation at different scales of space and time. Tournemire tunnel, southern France. Hydrogeol J DOI 10.1007/ s100400000119

Desbarats AJ, Hinton MJ, Logan CE, Sharpe DE (2001) Geostatistical mapping of leakance in a regional aquitard, Oak Ridges Moraine area, Ontario, Canada. Hydrogeol J DOI 10.1007/ s100400000110

Gautschi A (2001) Hydrogeology of a fractured shale (Opalinus clay) - implications for deep geological disposal of radioactive wastes. Hydrogeol J DOI 10.1007/s100400000117

Gerber RE, Boyce JI, Howard KWF (2001) Evaluation of heterogeneity and field-scale groundwater flow regime in a leaky till aquitard. Hydrogeol J DOI 10.1007/s100400000115

McMahon PB (2001) Aquifer/aquitard interfaces: mixing zones that enhance biogeochemical reactions. Hydrogeol J DOI $10.1007 / \mathrm{s} 100400000109$

Neuzil CE (1986) Groundwater in low permeability environments. Water Resour Res 22:1163-1195

Rodvang SJ, WW Simpkins (2001) Agricultural contaminants in Quaternary aquitards: a review of occurrence and fate in North America. Hydrogeol J DOI 10.1007/s100400000114

Sacchi E, Michelot J-L, Pitsch H, Lalieux P, Aranyossy J-F (2001) Extraction of water and solutes from argillaceous rocks for geochemical characterization: methods, processes, and current understanding. Hydrogeol J DOI 10.1007/s 100400000113

van der Kamp G (2001) Methods for determining the in situ hydraulic conductivity of shallow aquitards - an overview. Hydrogeol J DOI 10.1007/s100400000118 